\title{
METAFIZYCZNE IMPLIKACJE DOGMATÓW
}

\section{ANTYMETAFIZYCZNE NASTAWIENIE NOWEJ TEOLOGII PROTESTANCKIEJ}

Nowa teologia protestancka — od demitologizujących teorii R. Bultmanna aż po teologie śmierci Boga tradycji chrześcijańskiej, a nie tylko filozoficznego teizmu, wypracowane przez W. Hamiltona, Th. Altizera, D. Sölle - jest antymetafizyczna w tym znaczeniu, że odrzuca metafizykę i ma dla niej nawet pogardę. Przyswaja sobie bowiem odwrót od metafizyki, znamienny dla współczesnej filizofii: dla egzystencjalizmu, dla fenomenologii, dla angielskiej filozofii analitycznej. Przejmuje także model świata, stanowiący metodologiczną podstawę dzisiejszej nauki: świat jest rzeczywistością zamkniętą w sobie, w której powiązanie skutków z przyczynami jest takie, że nie zostawia miejsca na interwencje jakiegoś bytu pozaświatowego, Boga czy duchów. Ten metodologiczny model naukowy świata urósł w niektórych kierunkach nowej teologii, zwłaszcza w teologiach śmierci Boga, do rzędu podstawowej tezy światopoglądowej.

Co rozumie przez metafizykę, którą odrzuca? Nie mówi o niej w znaczeniu tradycyjnym, w którym metafizyka była tym samym co ontologia, czyli rozprawa o bycie - jakimkolwiek, w ogólności. Najczęściẹ chodzi o metafizykę rozumianą w znaczeniu przywiązanym do tego słowa przez Heideggera. Według niego metafizyka jest to - jak pisze w Holzwege - podstawowa struktura bytującego, rozróżniająca świat fizyczny i metafizyczny, gdzie świat pierwszy - to jest fizyczny - jest uzasadniony i zdeterminowany przez drugi, tj. metafizyczny: jest to rozróżnianie rzeczywistości ziemskiej i ponadziemskiej, wychodzące z założenia, że ta rzeczywistość ponadziemska podtrzymuje i determinuje rzeczywistość ziemską. Rzadziej chodzi o metafizykę rozumianą w znaczeniu 
przyjmowanym przez neopozytywistów i filozofię analityczną: w nim zaś metafizyką jest wszystko, co jest niedostępne doświadczalnemu sprawdzeniu.

M. Heidegger wywarł wielki wpływ na nową teologię nie tylko przez swą hermeneutykę egzystencji ludzkiej, której zasady wyłożył w dziele Sein und Zeit (Halle 1935), ale także przez walkę z tradycyjną metafizyką jako ontoteologią: Przez cały ciąg swych dziejów, od Arystotelesa począwszy, była ona nie tylko ontologią, ale równocześnie i teologią, bo jej przedmiotem był Bóg w taki sam sposób jak każdy inny bytujący, Seiender. Pełnił mianowicie funkcję ostatecznej, tłumaczącej zasady dla pozostałych bytujących. Sprowadzenie Boga do roli przedmiotu - czyli tzw. uprzedmiotowienie, obiektywizacja Boga - pociągnęło za sobą dwa skutki: Przez to, że człowiek tworzył sobie naukowe pojęcie, czyli przedstawienie Boga, uzależniał Go od siebie, panował nad nim. Stąd zaś wynikało z konieczności, że Bóg tradycyjnej, nawet tomistycznej filozofii nie był już przedmiotem religii. stracił cechy prawdziwie boskie; przestał być Bogiem boskim. Wszak nie można się modlić do bytującego, który jest tylko prima causa, primum ens; nie można ani składać mu ofiar, ani klękać z czcią ani śpiewać ani tańczyć na jego cześć. Heidegger dodawał, że metafizyka z założenia nie mogła nie być ontoteologią; że z swej istoty musiała uprzedmiotować Boga.

Odrzucenie metafizyki oznaczało więc nie tylko przekreślenie filozoficznego teizmu, nie tylko śmierć Boga tegoż teizmu, ale także pożegnanie tradycyjnego chrześcijańskiego obrazu świata oraz tradycyjnej chrześcijańskiej wiary.

\section{2. ŻĄDANIE TEOLOGII NIEMETAFIZYCZNEJ PRZEZ KATOLICKICH TEOLOGÓW NOWEJ LINII}

Historycznie najwcześniejszym przykładem niemetafizycznej teologiı w katolicyzmie było opracowanie obecności eucharystycznej, przedstawione później w holenderskim Nowym Katechizmie, De Nieuwe Katechismus z r. 1966, a przygotowane przez P. Schoonenberga i kolegów z Instytutu Katechetycznego w Nimwegen. Odrzuca ono tradycyjne ujęcie metafizyczne, a posługuje się fenomenologiczną analizą egzystencjalną Heideggera z Sein und Zeit; mówi o transsignifikacji i transfinalizacji, a pomija przeistoczenie czyli transsubstancję. To zastosowanie Heideggerowej hermeneutyki do nowej interpretacji dogmatu eucharystycznego okazało się jednak zarówno nieporadne w sobie jak niebezpieczne dla dogmatycznej treści i stało się okazją do encykliki Mysterium fidei. E. Schillebeeckx - w dziełku Die eucharistische Gegenwart (196?) — pogłębił 
więc niemetafizyczne tłumaczenie tej obecności posługując się, na odmianę, fenomenologią M. Merleau-Ponty'ego, która dopuszczała wprawdzie w Eucharystii zmianę w charakterze bytowania chleba, transentatio, ale nie miała miejsca dla transsubstantiatio. A zastosowanie fenomenologii - z odrzuceniem metafizyki — do teologicznej interpretacji kluczowych dogmatów Trójcy Sw. i Wcielenia doprowadziło holenderskich teologów nowej linii do rezygnacji z preegzystencji Słowa, odwieczności Ducha Sw., bóstwa Jezusa Chrystusa.

Przytoczone fakty i przykłady wyrastały z przyjętego już modelu nowej teologii, ale wyprzedziły wyraźne i metodyczne sformułowanie jej programu. Dostarczył go, we wrześniu 1970 r., uczestnikom słynnego, brukselskiego kongresu teologów, E. Schillebeeckx w swym referacie pt. Le statut critique de la thélogie ${ }^{1}$. Myśli naszkicowane w tym, przeładowanym treścią, wystąpieniu wyłożył on szeroko w $1971 \mathrm{r}$. w dziele: Glaubensinterpretation. Beiträge zu einer hermeneutischen und kritischen Theologie (Mainz 1971). Teologia, czytamy tam, ,,jest to hermeneutyczna aktualizacja apostolskiej wiary" 2. Aby nią była, naprzód jej wypowiedzi muszą być sensowne; a będą takie, jeśli będą związane z doświadczeniem religijnym społeczności wiernych: wymaganie sensowności nawiązuje do filozofii analitycznej Wittgensteina. Jest zaś hermeneutyczna dlatego, że stosuje zasadę ,późnego" Heideggera — z dziela Unterwegs zur Sprache (Tübingen 1954) — że byt objawia się w słowie; że mowa ludzka ma ontologiczny wymiar. Wreszcie nowa teologia jest krytyczna, albowiem ,,jest krytyczna samoświadomością praktyko-wania wiary w świecie i w Kościele", a do tej krytyki służy jej wszystko to, co sensownego i bezsensownego w człowieku i w społeczeństwie odkrywają nauki analityczne i hermeneutyczne ${ }^{3}$. Natchnienie do postulowania krytycznego charakteru nowej teologii wyszło od szkoły frankfurckiej, głównie od J. Habermasa i jego dzieła Theorie und Praxis (Neuwied 1969).

W dziele E. Schillebeeckxa widać brak scalenia, który można wytłumaczyć tym, że jest ono zbiorem artykułów napisanych w różnych okolicznościach. Widać również ważkie niedomówienia, jak gdyby autor rozmyślnie kazał czytelnikowi wyciągać wnioski z postawionych tez. Natomiast bez niedomówień i w jednym rzucie przedstawia program nowej teologii C. Geffré z Saulchoir. A ponieważ jego programowe postulaty są świeższej daty niż dzieło Schillebeeckxa - pochodzą bowiem z r. 1972 - one będą punktem odniesienia i porównania dla naszych rozważań o metafizycznych implikacjach dogmatów.

„Concilium”, 1970, nr 60 supplément: Avenir de l'Eglise, 61-68.

Dz. cyt., 157.

Dz. cyt., 171. 
Model nowej teologii przedstawia C. Geffré w książce Un nouvel âge de théologie (Paris 1972); w artykule Sens et non-sens d'une théologie non métaphysique („Concilium”, 1972, nr 76, 89-98); w brukselskim sympozjum na temat Boga, z marca 1972, streszczonym przez „Revue Théologique de Louvain" (1972, nr 4, $487 \mathrm{nn}$.). Wszystkie trzy publikacje zawierają te same zasadnicze myśli, ale artykuł wypowiada je mocniej i wyraźniej niż książka, a już bez żadnych ogródek przedstawia je Geffré na brukselskim sympozjum.

Geffré, powtarzając określenie powszechnie przyjmowane przez teologów nowej linii, powiada, że teologia jest interpretacją doświadczenia chrześcijańskiej społeczności. W dobie końca metafizyki musi ona być niemetafizyczną, ale pozostanie nadal ontologiczną. Jak tradycyjna metafizyka istnienie wszystkich bytujących tłumaczyła przez pierwszego bytującego Boga, primum ens, tak również tradycyjna teologia d̄latego była metafizyczna, że treść objawienia opierała na pojęciu Boga jako pierwszego bytu, ens a se, czy esse subsistens. Po wtóre, jak w tradycyjnej metafizyce, jako ontoteologii, również w teologii metafizycznej Bóg był przedmiotem obiektywizujących pojęć i twierdzeń. Tymczasem Bóg religii — jak wykazała krytyka metafizycznej ontoteologii przeprowadzona przez Heideggera - w ogóle nie może być przedmiotem żadnego pojęcia, bo poprzez pojęcia rozum dominuje nad przedstawionymi w nich przedmiotami. Skoro więc Bóg religii i objawienia wyklucza możność obiektywizacji czyli uprzedmiotowienia, nowa teologia nie może być ani metafizyczna ani obiektywizująca Boga, jego przymiotów, jego czynności.

Powstaje pytanie: Jak może ona w ogóle mówić o Bogu, jeśli nie jest On dla niej przedmiotem? Rozwiązania tej pozornej sprzeczności dostarcza, zdaniem Geffrégo, Heidegger w Unterwegs zur Sprache, gdzie rozwija ontologię mowy, twierdząc, że byt objawia się przez mowę i że wypowiedź mowy nie jest ograniczona do formułowania zdań o przedmiotach.

Nowa teologia, chociaż niemetafizyczna, będzie jednak ontologiczna, bo będzie rozprawą o bytach, o rzeczywistości; będzie wprost te ologią rzeczywistości. Będzie także teologią hermeneutyczną, albowiem tak dane objawienia jak doświadczenia społeczności chrześcijańskiej będzie interpretować zgodnie z zasadami hermeneutyki Heideggera-Gadamera; zatem w horyzoncie hermeneutycznym właściwym dla Boga chrześcijańskiego objawienia. Chociaż hermeneutyczna, to jednak treści objawienia nie zredukuje do egzystencjalnego sensu ludzkiego i nie będzie antropocentryczna, jak to czyni niejedna hermeneutyka egzystencjalistyczna. 
Oto najważniejsze następstwa niemetafizycznego oraz hermeneutycznego modelu nowej teologii przedstawionego przez Geffrégo. Właściwym horyzontem hermeneutycznym dla teologicznej rozprawy o Bogu, w której Bóg przedstawi się jako prawdziwie boski, nie jest filozoficzny horyzont istoty - niezmiennej i nieskończenie doskonałej - ale horyzont historii; dokładniej mówiąc horyzont historii zbawienia i eschatologii, która jest jej częścią i kresem. Wynika stąd, że w wykładzie nauki o Bogu nowa teologia winna zrezygnować z tych wszystkich atrybutów Boga, które należą do horyzontu filozoficznego i obiektywizują Boga, a zatem są fałszywe. Ponieważ o boskim Bogu możemy mówić jedynie w horyzoncie historii, należy w szczególności zaprzestać przypisywania $\mathrm{MIu}$ niezmienności i nieskończonej doskonałości. Bytowanie Boga jest ciągłym stawaniem się i nie teraźniejszość — według metafizycznej teologii niezmienna i nieprzemijająca - lecz przyszłość jest najbardziej podstawą biblijnego pojęcia Boga. Kenoza Boga zajmie więc w przyszłej t€ologii miejsce nieskończonej doskonałości. Przyznanie przyszłości w bytowaniu Boga pierwszeństwa przed teraźniejszością nawiązuje do teologii nadziei J. Moltmanna, który biblijne samookreślenie Boga ehjeh. aszer ehjeh tłumaczy przez „B ę dę, który będę”, a nie „Jestem, który jestem", jak to tradycyjnie rozumiano. Z tej zaś kenozy Boga wypływa, że przeciwstawienie Boga światu zniknie na korzyść stosunku dialektycznego, w którym świat nie będzie tylko stroną odbierającą, ale i dającą.

Są to tylko niektóre następstwa proponowanego modelu nowej teologii; w wspomnianym sympozjum brukselskim C. Geffré wymienia ich więcej: Ale te, które wyżej przytoczono, mówią wystarczająco jasno, jak głębokie zmiany do tradycyjno-katolickiego pojęcia Boga wprowadza jego model teologii hermeneutycznej i niemetafizycznej.

\section{ZAGADNIENIA DO ROZWIAZZANIA}

Pytania, jakie stają obecnie przed nami do rozwiązania, są narzucone przez dotychczasowy rozwój nowej teologii tak w protestantyzmie jak $\mathrm{w}$ katolicyzmie oraz przez jej filozoficzne zaplecze czyli przede wszystkim przez wczesną i późną myśl M. Heideggera. W swym początkowym okresie teologia nowej linii w katolicyzmie chciała być t y lko hermeneutyczna; ograniczaìa się więc do sensu egzystencjalnego, ludzkiego, a przez to była antropocentryczna. Taką była zwłaszcza teologia uprawiana przez P. Schoonenberga w późnych latach sześćdziesiątych. Według najnowszego modelu, zaproponowanego przez Geffrégo, ma ona być trójprzymiotnikowa: tj. hermeneutyczna, ontologiczna, niemetafizyczna. Charakter hermeneutyczny i niemetafizyczny jest 
więc nieodłączną, istotną ccehą teologii nowej linii, a ontologiczność pojawiła się później, jako reakcja przeciwko zbyt subiektywnemu i zawężającemu programowi teologii czysto hermeneutycznej i antropocentrycznej. Niezmiennym tłem, na którym się rozwija teologia nowej linii, jest Heideggerowska krytyka tradycyjnej metafizyki i przedmiotowości Boga oraz jego „ontologia mowy”, jako środek zaradczy.

Pierwsze trzy pytania są narzucone przez trzy przymioty teologii nowej lini:

a) Czy nowa katolicka interpretacja teologiczna dogmatów może się ograniczyć wyłącznie do hermeneutycznego sensu egzystencjalnego i tym sposobem być antropocentryczna?

b) Czy nowa katolicka interpretacja teologiczna dogmatów musi z konieczności posiadać znaczenie przedmiotowe, odnoszące się do bytów rzeczywistych - zatem ontologiczne; niezależne od sensu egzystencjalnego dla człowieka; istniejące nawet wtedy, gdy sens hermeneutyczny albo nie istnieje albo nie jest widoczny?

c) Czy nowa katolicka interpretacja teologiczna dogmatów może być naprawdę i całkowicie niemetafizyczna? Względnie, czy musi być nie tylko ontologiczna ale i metafizyczna, przynajmniej w niektórych rozdziałach?

Odpowiedź na to pytanie trzecie posiada największe znaczenie dla określenia nowej interpretacji dogmatów, do której chcemy wprowadzić uczestników sympozjum. Z tego właśnie powodu ono posłużyło za tytuł dla tego wykładu.

Aby odpowiedź mogła być całkowicie jednoznaczna, musi być wprzód możliwie najściślej określone, co należy rozumieć przez każde z trzec’n powyższych pytań. Pojęcie znaczenia hermeneutycznego czyli egzystencjalnego oraz znaczenia przedmiotowego - które w dogmatach i teologii dogmatycznej jest również ontologiczne, bo odnosi się do bytów rzeczywistych - zostało już wystarczająco wyjaśnione w moim wczorajszym referacie. W jego świetle sens dwu pierwszych pytań jest dostatecznie jasny i nie wymaga dodatkowych wyjaśnien.

Inaczej jest $\mathrm{z}$ pytaniem trzecim; tym bardziej, że $w$ odniesieniu do niego Geffré, w artykule z „Concilium” 1972, wspomnianym wyżej, popełnił klasyczny błąd wieloznaczności, fallacia aequivocations. Albowiem wielokrotnie i jako główny swój zamysł przedstawiał model przyszłej, niemetafizycznej teologii, a z drugiej strony wyraźnie napisał: „Z punktu widzenia filozofa, język teologii jest z konieczności metafizyczny, przynajmniej w tym najogólniejszym znaczeniu, że nie jest doświadczalnie sprawdzalny" ${ }^{4}$. Z czego taki skutek, że czytelnik ostatecznie nie wie, 
czy w modelu Geffrégo przyszła teologia właściwie będzie niemetafizyczna, a jeśli będzie, to w jakim znaczeniu. Ten pospolity błąd logiczny mocno podważa wartość naukową całości wywodów Geffrégo.

Znaczenie słów bywa określane przez kontekst. Podobnie znaczenie trzeciego pytania musi być ustalone przez odniesienie do historycznego kontekstu, w którym się zrodziło. Cała zaś dyskusja nad niemetafizycznym charakterem nowej teologii nie tylko została wywołana przez Heideggerową krytykę tradycyjnej metafizyki, ale także przejęła jego argumentację i jego terminologię. Dlatego słowa „metafizyka”, „metafizyczny" posiadają w niej zasadniczo takie znaczenie, jakie im nadał Heidegger. A metafizyką według niego - jak już powiedziano w ustępie pierwszym - jest rozróżnienie rzeczywistości ziemskiej od ponadziemskiej i założenie, że ponadziemska rzeczywistość podtrzymuje i determinuje rzeczywistość ziemską. Nazwa ,rzeczywistość ziemska” w tym określeniu ma znaczenie szersze, tj. znaczenie rzeczy wistości św iat o w e j, a nazwa „rzeczywistość ponadziemska” oznacza właściwie i ściśle rzeczywistość ponadśsiatową. Zakres pojęcia ,metafizyka" jest w tym znaczeniu znacznie węższy niż zakres metafizyki rozumianej w znaczeniu tradycyjnym. Wszystko, co dotyczy bytu, rzeczywistości, w tradycyjnym znaczeniu należy do metafizyki czyli onto logii, $\mathrm{tj}$. do rozprawy o bycie; w znaczeniu Heideggerowskim zaś należy do ontologii, a nie do metafizyki; metafizyka w jego znaczeniu obejmuje swym zakresem tylko rzeczywistość ponadświatową oraz jej stosunki do rzeczywistości światowej. Np. wewnętrzne uświęcenie człowieka należy do ontologii, jak długo rozpatrujemy je jako wydarzenie dokonujące się W świecie ludzkiego bytowania; przejdzie zaś do metafizyki z ta chwilą, gdy powiemy, że dokonuje się mocą i interwencją łaski Boga. Na rzeczywistość ponadświatową składają się według Heiddegera Bóg i duchy, dobre oraz złe.

Sens trzeciego pytania jest zatem w takim kontekście następujący: Czy zachowując nienaruszoną treść dogmatów - można zbudować naukową teologię katolicką w taki sposób, by zrezygnować z istnienia rzeczywistości pozaświatowej; nie będącej częścią świata; rzeczowo i istotnie od świata różnej? Ale teologia etymologicznie jest rozprawą o Bogu, który jest jej głównym przedmiotem. Wobec tego sens trzeciego pytania można wyrazić jeszcze przejrzyściej w taki sposób: Czy zachowując nienaruszoną treść dogmatów katolickich, można zbudować taką ich teologiczną interpretację, w której by Bóg był częścią świata i nie różnił się od niego rzeczowo oraz istotnie?

Zarzut uprzedmiotowiania, obiektywizacji Boga skierował Heidegger pod adresem tradycyjnej metafizyki filozoficznej i tradycyjną metafi. zykę za to krytykował. Ale z dotychczasowej historii teologii nowej linii 
widać, że jej przedstawiciele — tak protestanccy jak katoliccy — uznali, że zarzuty i krytyka Heideggera są ważne również w odniesieniu do tradycyjnych teologicznych rozpraw o Bogu; dlatego mozolą się nad zbudowaniem niemetafizycznej teologii. Rozważania nasze są teologiczne i dlatego nie będziemy pytać, w jakiej mierze Heideggerowe zarzuty postawione tradycyjnej metafizyce są słuszne. Zmuszają nas jednak do postawienia pytania ściśle teologicznego. Mianowicie, istotnym i właściwym, czyli najbardziej bezpośrednim przedmiotem badania $\mathrm{w}$ katolickiej dogmatyce jest treść katolickiej nauki wiary, a w jej zakresie przede wszystkim treść dogmatów. Dlatego w związku z Heideggerową krytyką stawiamy czwarte, ściśle teologiczne pytanie: Czy Bóg jest w właściwym znaczeniu przedmiotem treści dog m a tów?

Nie ulega najmniejszej wątpliwości, że w wielu wypowiedziach dogmatycznych Bóg występuje jako podmiot zdania, np. w sądzie: „Bóg jest istotnie i rzeczowo różny od świata". Ale problem leży w tym, czy będąc podmiotem wypowiedzi dogmatycznej równocześnie jest także jej przedmiotem, rozumianym w znaczeniu właściwym i ścisłym. Przedmiotem $\mathrm{w}$ znaczeniu właściwym i istotnym, obiectum proprium et formale, poznania lub wypowiedzi jest tylko to, co przez poznanie lub wypowiedź osiągnięte jest wprost i bezpośrednio. Wszystko zaś, co zostaje wprawdzie dosięgnięte, ale tylko pośrednio, właściwie czyli naprawdę nie jest już przedmiotem: wprawdzie bywa nazywane przedmiotem, ale w znaczeniu szerszym, niewłaściwym. Zwykliśmy np. mówić w potocznej mowie: „W lustrze widzę meble znajdujące się w pokoju”. Łatwo dostrzec, że jest to wyrażenie nieścisłe i nie wyrażające tego, co właściwie się dzieje. Wszak w lustrze widzę, prawdę mówiąc, tylko odbicie mebli znajdujących się $\mathrm{w}$ pokoju, a nie meble. Wobec tego czwarte pytanie ma następujące znaczenie: Czy Bóg, czyli jego boskie jestestwo, bywa dosięgnięty przez treść dogmatów prawdziwie bezpośrednio - z wykluczeniem pośrednictwa jakiegokolwiek przedmiotu wprzód i bezpośrednio oznaczonego? A w nawiązaniu do Heideggerowej krytyki uprzedmiotowienia Boga $w$ metafizyce pytamy w nim, czy można treść katolickiej i dogmatycznejnauki o Bogu obwiniá o obiektywizację Boga.

Nie jest to pełny wykaz pytań, na które trzeba będzie odpowiedzieć. Pozostałe pytania wyłonią się bowiem dopiero w toku naszych rozważań z odpowiedzi, jakie padną na powyższe cztery. A najważniejsze z nich będzie następujące: Jakie metafizyczne założenia są nieodzownie konieczne do nowej, katolickiej interpretacji teologicznej dogmatów? 
4. METAFIZYCZNE ORAZ HERMENEUTYCZNE TRESCI IMPLIKOWANE PRZEZ PODSTAWOWE DOGMATY CHRZEŚCIJAŃSTWA

Treści metafizycznych i hermeneutycznych będziemy poszukiwać w dogmatach wiary, które są tak podstawowe dla chrześcijaństwa, że albo stały się dogmatami od początku istnienia Kościoła z powszechnego nauczania zwykłego i nie wymagały uroczystego definiowania, albo zostały włączone do uroczystych formuł wyznania wiary. A za treści metafizyczne, zgodnie z zawężonym znaczeniem przyjętym w ustępie trzecim, będziemy uważać te, które dotyczą rzeczywistości pozaświatowej i jej wpływu na świat. W referacie inauguracyjnym wyjaśniłem szerzej, co należy rozumieć przez sens hermeneutyczny czyli egzystencjalny. Treści te odnajdujemy łatwo w dogmatach stworzenia z niczego, opatrzności Bożej, wcielenia. Są one zawarte również w treści innych artykułów Credo i innych dogmatów, ale poszukiwania rozmyślnie ograniczamy do trzech wspomnianych dlatego, że wśród dogmatów katolickiej wiary są najbardziej podstawowe i dają wystarczającą podstawę do wnioskowania o naturze nowej katolickiej teologii.

Już I sobór powszechny w Nicei, 325 r., zaliczył stworzenie do podstawowych prawd albowiem mówi o nim dwukrotnie w swym wyznaniu wiary. W jego pierwszym artykule czytamy: ,Wierzymy w jednego Boga, Ojca wszechmogącego, wszystkich rzeczy widzialnych i niewi-dzialnych stworzyciela" (DS 125). Artykuł drugi, poświęcony Bogu Synowi, mówi zaś o Synu Bożym ,przez którego wszystko się stało tak w niebie jak na ziemi". W tych zwięzłych formułach nicejskich zawarte są już wszystkie istotne treści dogmatycznej nauki o stworzeniu z niczego. Późniejsze wyjaśnienia Magisterium dodadzą tylko dwie cechy: akt stworzenia jest wolny od wszelkiej konieczności oraz dokonał się na początku czasu, bo tak uczy Pismo św. i Tradycja. Poza tym będą jedynie mówić wyraźnie i po imieniu to samo, co niewyraźnie przyjmował za dogmatyczną treść już I sobór nicejski. Innymi słowy jak daleko w przeszłość możemy śledzić wiarę Kościoła w akt stworzenia, stwierdzamy, że przywiązywał do niego zawsze tę samą treść.

Do tej treści należy zaś rzeczowa i istotna różnica między Bogiem a wszystkim co nie jest Bogiem, czyli światem: tylko Bóg nie jest uczyniony przez nikogo, a wszystko co nie jest Bogiem, czyli świat, zostało stworzone przez Boga. Po wtóre nie zostało uczynione z substancji Bożej; nie tak jak dziecko przychodzące na świat bywa utworzone z substancji ojca i matki - ale zostało stworzone z niczego, bez żadnego tworzywa. Gdyby pochodziło z substancji Bożej, miałoby w sobie pokrewieństwo z Bogiem; a dlatego, że zostało stworzone $\mathrm{z}$ niczego, nie ma z Bogiem żadnego pokrewieństwa, jest zasadniczo innego rodzaju niż Bóg. 
Wreszcie Bóg stworzył wszystko nie z wewnętrznej konieczności; nie dlatego, że musiał; ale stworzył dlatego, że dobrowolnie chciał stworzyć; i stworzył wtedy, kiedy chciał. Postanowił zaś stworzyć i stworzył na początku czasu - jak uczy Pismo św. i określa dogmatycznie sobór lateraneński IV 1215 r. (DS 800) - a nie przed wszystkimi wiekami. Między Bogiem a światem, tj. wszystkim co nie jest Bogiem, nie ma zatem żadnego koniecznego, istotowego powiązania. Bóg nie potrzebuje świata, ani nie jest częścią świata, bo dodawać się i tworzyć razem jakąś całość mogą tylko rzeczy tej samej natury, a Bóg — jak wyżej powiedziano -jest zupełnie innej natury niż świat, czyli wszystko co nie jest Bogiem. Innymi słowy Bóg stworzyciel jest rzeczywistością pozaświatową czyli metafizyczną w zawężonym, Heideggerowskim znaczeniu. Dogmat stworzenia uzależnia zatem istnienie całego świata od Boga, rzeczywistości pozaświatowej, a tym samym zmusza nas do zachowania - przynajmniej na tym odcinku - metafizycznego obrazu świata.

Sobór lateraneński IV 1215 r., idąc za nauką Starego i Nowego Testamentu, jako dogmat wiary określił twierdzenie, że Bóg stworzył świat na początku czasu (DS 800). Nie ma historii bez czasu; każda historia dzieje się w jakimś czasie. Z wyjaśnienia dogmatu stworzenia dokonanego przez sobór lateraneński wynika zatem, że historia w ogóle ma swój początek; że zaczęła się przed skończonym okresem czasu w chwili stworzenia świata. Dogmat stworzenia stawia nas zatem wobec nastẹpującego stanu rzeczy: zanim się zaczęła jakakolwiek historia, Bóg stworzyciel już jest. Ten stan rzeczy pociąga za sobą bardzo doniosłe następstwo: ani horyzont historii zbawienia ani w ogóle horyzont historii nie jest wystarczający do tego, by w sposób właściwy i pełny interpretować i rozumieć katolicką naukę dogmatyczną o Bogu, który jest stworzycielem świata. Bóg stworzyciel nie mieści się w żadnej historii; wyrasta poza nią. Jeśli więc nową interpretację dogmatów uprawialibyśmy tak, że Bogu przypisalibyśmy tylko to, na co zezwala horyzont historii zbawienia - jak nam podsuwa Geffré - z całą pewnością logiczna konieczność doprowadziłaby nas do tego, że zrezygnowalibyśmy z niejednej treści dogmatycznej. Taka interpretacja byłaby wprawdzie nowa, ale nie katolicka. W związku z tym ciśnie się na usta pytanie, skierowane do filozofów: Czy przypadkiem właściwym horyzontem do tego, by rozumieć tego bytującego, który już jest, zanim zaczęła się jakakolwiek historia, nie jest jednak horyzont istoty, ale pojętej niematematycznie i nie po platońsku?

Dogmat przypisuje akt stworzenia Bogu wszechmogącemu. Żaden inny przymiot nie bywa w nauczaniu kościelnym orzekany o Bogu tak często jak wszechmoc. Nie było wyznania wiary, które by o niej milczało. Mówiąc o wszechmocy Boga Kościół ma na myśli moc nieograni- 
niczoną; rozciągającą się na wszystko bez żadnego zacieśnienia; innymi słowami moc nieskończoną. Kenoza Boga, tj. rezygnacja z jego nie-skończonej doskonałości jest zatem nie do pogodzenia z treścią dogmatu o stworzeniu.

Dogmat o stworzeniu z niczego oprócz przedmiotowego znaczenia me-tafizycznego ma w wyznaniach wiary również egzystencjalny czyli hermeneutyczny sens. Mianowicie wszechmoc przypisują one Bogu jako Ojcu. Czyjemu Ojcu? Nie tylko jako Ojcu Jezusa Chrystusa, Boga Syna, ale także jako naszemu Ojcu, tj. Ojcu wszystkich ludzi. Albowiem Bóg jest Ojcem wszystkich ludzi w tym, biblijnym znaczeniu, że wszystkich ludzi darzy całkowicie bezinteresowną miłością i wszystkimi się opiekuje tak jak ojciec własnymi dziećmi. Dlatego zaś, że jest wszechmocny, może nam dać wszystko, czego potrzebujemy i co nam dać chce. Z tego powodu możemy zdać się całkowicie na wolę Boga i żyć w spokoju o nasz los; wszechmocny Ojciec pokieruje nim z pewnością dla naszego dobra.

Egzystencjalny sens hermeneutyczny zawarty jest wszakże przede wszystkim w samym akcie stworzenia $z$ niczego i na nim budowali swe życie wewnętrzne wszyscy święci. Stworzenie z niczego jest bowiem doktrynalną podstawą chrześcijańskiej pokory przez to, że wskazuje, iz sami z siebie bylibyśmy niczym, a wszystko co mamy i czym jesteśmy otrzymaliśmy od Boga. Podkreślając nasz dystans od Boga, wiekuistego i nieskończenie doskonałego, jest ono także pobudką do wdzięczności wobec Boga i dziękczynienia Bogu za to, że dobroć Jego przezwycięża ten dystans i ciągle jest dla nas bez zastrzeżeń hojna. Zaznaczyć należy, że ten hermeneutyczny sens stworzenia $z$ niczego nie przekreśla jego sensu przedmiotowego i metafizycznego; przeciwnie, zakłada go i wynika $\mathrm{z}$ niego.

Ale dogmatycznej treści kościelnej nauki o stworzeniu z niczego nie podobna — bez jej zubożenia i zniekształcenia — sprowadzić całkowicie do sensu czysto egzystencjalnego, hermeneutycznego.

Analiza dogmatycznej treści, przeprowadzona wyżej, wykazała bowiem, że właściwie, czyli wprost i bezpośrednio, oraz wyraźnie wypowiada ona sądy o przedmiotowej rzeczywistości metafizycznej, a nie o jej miejscu i znaczeniu dla naszej ludzkiej egzystencji. Zadne wyznanie wiary, żadne orzeczenie dogmatyczne w sprawie aktu stworzenia nie mówi wprost o jego egzystencjalnym sensie, ale o jego przedmiotowej rzeczywistości. Sens egzystencjalny albo wynika z przedmiotowego, czyli jest sensem wtórnym, pochodnym, albo jest ubocznie i niewyraźnie podsunięty, insynuowany lecz nie wypowiedziany. Gdybyśmy więc chcieli ograniczyć się do sensu hermeneutycznego, musielibyśmy odrzucić prawie całą treść dogmatyczną kościelnej nauki o stworzeniu z niczego.

Po drugie, w przedmiotowej treści dogmatu stworzenia są aspekty, 
które są albo zaprzeczeniem zasad hermeneutyki egzystencjalnej albo są przez nią nie osiągalne. W treści dogmatu zawiera się naprzód zaprzecze-nie samej zasady, na której się opierała egzystencjalna hermeneutyka antropocentryczna, która święciła triumf w początkowym okresie rozwojowym teologii nowej linii. Zapożyczona z Heideggerowego Sein und Zeit zasada ta orzekała, że bytowanie każdego bytującego w swej głębi polega na bytowaniu w odniesieniu do człowieka. Tymczasem sobór watykański I, 1870 r., w Konstytucji dogmatycznej Dei Filius, za treść dogmatyczną uznał twierdzenia: świat został stworzony na chwałę Bożą (DS 3025), a Bóg jest celem wszech rzeczy (DS 3002). O sensie każdego bytowania rozstrzyga cel, do którego ono zmierza. Jeśli więc razem z soborem uznamy, że Bóg jest celem wszystkiego, to przez swoje odniesienie do Boga, a nie przez odniesienie do człowieka, wszystko co bytuje ma ostateczny sens swego bytowania. Jeśli natomiast będziemy obstawać przy zasadzie hermeneutycznej, że najgłębszego sensu nabiera wszystko przez odniesienie do człowieka, będziemy zmuszeni logiczną koniecznością wynikania odrzucić dogmatyczną naukę I soboru watykańskiego o celu stworzenia ś́wiata.

Gdybyśmy nie przyjmowali zasady hermeneutycznej tak wyraźnie antropocentrycznej, tzn. gdybyśmy nie zakładali, że bytowanie jakiekolwiek w swej głębi polega na bytowaniu w odniesieniu do człowieka, a opowiedzieli się za bardziej umiarkowanym, dzisiaj zaś rozpowszechnionym założeniem hermeneutycznym, że rozumienie wiary jest rozumieniem siebie, to nawet przy takim założeniu sa w dogmacie stworzenia przedmiotowe treści, których się nie da sprowadzić do tak zdefiniowanego sensu hermeneutycznego; treści, z których by trzeba było zrezygnować, gdyby interpretacja dogmatów miała się ograniczyć do ich hermeneutycznego, egzystencjalnego sensu. Taką treścią jest stworzenie świata na początku czasu połączone z odwiecznym istnieniem Boga przed stworzeniem. Objawia się w niej tylko wielkość i tajemniczość Boga stworzyciela, ale nie wnosi ona niczego do rozumienia naszego ludzkiego bytowania. W imię tej właśnie zasady niektórzy holenderscy teologowie nowej linii zaprzestali mówić o preegzystencji Słowa i o odwiecznym istnieniu Ducha Sw. Syn Boży, ich zdaniem, istnieje dopiero od chwili wcielenia, a Duch Sw. dopiero od chwili zesłania, albowiem dopiero od teg momentu ich istnienie zaczyna kształtowaé i zarazem tłumaczyć naszą ludzką egzystencję.

Opatrzność, czyli opieka Boga nad światem, jest, podstawowym dogmatem nie tylko chrześcijaństwa, ale każdej rozwiniętej religii. Dlatego, że jest to tak bardzo podstawową prawdą, jej istnienie stało się dogmatem z powszechnego nauczania zwykłego, a sobór watykański I, w Konstytucji Dei Filius, naukę Tradycji w nastę- 
pujących słowach uroczyście i dogmatycznie wyraził: „,Wszystkim zaś, co stworzył, Bóg przez swą opatrzność się opiekuje i zarządza... Wszystko bowiem odkryte i odsłonięte jest przed jego oczami, również i to, co się stanie w przyszłości wolną czynnością stworzeń” (DS 3003).

Nie ulega wątpliwości, że dogmat opatrzności jest o wiele bogatszy w sens hermeneutyczny niż dogmat stworzenia z niczego, ale równocześnie jest prawdą, że dopiero przez swą opatrzność Bóg stworzyciel wkracza w historię świata jako rzeczywistość wprawdzie innego rodzaju niz wszystko, co jest częścią świata, ale rzeczywiście i aktualnie w nim działająca i obecna; dopiero istnienie opieki Bożej nad światem sprawia, że świat widziany przez religię chrześcijańską ma kształt modelu metafizycznego, przeciwko któremu walczy teologia nowej linii; jest nie tylko otwarty na działanie wszechmocnego i nieskończenie doskonałego Boga, który nie jest jego częścią, ale tego działania nieustannie potrzebuje do tego, by nadal istnieć.

Również konkretne przykłady działania opatrzności wymieniane w wyznaniach wiary mają przedmiotowy sens i zawierają metafizyczną treść: Kościoł święty jest rzeczywistością złożoną, widzialną i niewidzialną; jako rzeczywistość niewidzialna obejmuje Chrystusa i Ducha Sw., który jest w nim stale obecny i stale działa tak, jak dusza w ciele ludzkim. Sakramenty, sprawowane przez Kościół - np. chrzest na odpuszczenie grzechów - są nie tylko widzialnymi czynnościami ludzi, ich szafarzy, ale także czynnościami Chrystusa i Boga, którego wszechmoc aktualnie sprawia ich skutek. Odpuszczenie grzechów dokonuje siẹ wprawdzie w nas, w naszych duszach, ale jest skutkiem łaski, której właściwą przyczyną jest wszechmocny Bóg. Odrzucenie metafizycznego obrazu świata równałoby się zatem zasadniczej zmianie treści w pojęciach Kościoła, sakramentów i łaski.

Istnienie opatrzności ma dla człowieka przede wszystkim sens egzystencjalny i to najdonioślejszy: mianowicie od opatrzności, która dobro wynagradza a zło karze, oczekuje wierzący ostatecznego wyjaśnienia sensu i to nie tylko sensu jego osobistego życia, ale również sensu historii; zarówno historii ludzkości jak całego świata. Dzięki opatrzności staje się dopiero sensowna religia oraz wszystkie jej przejawy i formy: cześe, ufność i miłość dla Boga, modlitwa, ofiary, wypełnianie przykazań Bożych czyli religijna etyka.

Sens egzystencjalny wiary $w$ opatrzność zakłada jednak jej sens przedmiotowy, metafizyczny tak, że bez niego nie może istnieć. Wszak tylko wtedy możemy oczekiwać od Boga ostatecznego wyjaśnienia sensu życia i historii, jeśli jest obiektywną prawdą, że Bóg jest nieskończenie mądry, nieskończenie dobry i nieskończenie mocny, oraz wszystkim, co jest w świecie, tak skutecznie kieruje, że bez woli Jego nic się stać nie 
może. Tylko wtedy ma sens niezachwiana ufność wobec Boga, jeśli jest przedmiotowo prawdziwe, że Bóg istotnie jest moim wszechmocnym i wszystko wiedzącym Ojcem i dlatego chce dla mnie tylko dobra, wie co jest dla mnie dobre i ma moc dać mi to dobro. Podobnie rzecz się ma $z$ innymi objawami egzystencjalnego sensu hermeneutycznego katolickiej wiary w opatrzność.

Podstawowe treści wiary $\mathrm{w}$ Jezusa Chrystusa, czyli w wcielenie określił już I sobór konstantynopolitański w wyznaniu wiary, które bywa odmawiane w liturgii mszalnej nie tylko obrządku bizantyńskiego, ale również rzymskiego. Drugi jego ustęp, poświęcony Panu Jezusowi, jest niezwykle bogaty $\mathrm{w}$ treści metafizyczne, bo nie tylko uzależnia rzeczywistość ziemską od pozaświatowej, ale umieszcza rzeczywistość pozaświatową W pośrodku rzeczywistości ziemskiej. O człowieku Jezusie twierdzi bowiem nie tylko, że przyjął ciało i stał się człowiekiem czyli narodził się z Maryi, ale także że jest jedynym rodzonym Synem Boga stworzyciela; zrodzonym przez niego przed wszystkimi wiekami, współistotnym Bogu Ojcu i prawdziwym Bogiem. A jego ludzkie narodzenie z dziewicy Maryi przypisuje pozaświatowej, boskiej mocy Ducha św.

W świetle przekazu Ewangelii św. Jana już sam Jezus, za swego ziemskiego życia, był świadomy jak wielkie znaczenie egzystencjalne dla ludzi ma nie tylko jego działalność i nauka, a zwłaszcza śmierć, ale również jego osobowość. Mówił mianowicie: „Ja jestem drogą i prawdą i życiem" (J 14, 6). Całe bogactwo egzystencjalnego sensu wcielenia wyraził $1 \mathrm{~J}$ 5,20 w pokrewnej formule: „On jest prawdziwym Bogiem i żywotem wiecznym". Poczynając od najpierwszych lat istnienia Kościoła, naprzód Apostołowie, a potem święci i teologowie rozmyślając odkrywali coraz to inne aspekty hermeneutycznego sensu wcielenia. Juz św. Paweł pisał o Bogu: „On, który nawet własnego Syna nie oszczędził, ale go za nas wszystkich wydał, jakże miałby nam wraz z Nim i wszystkiego nie darować?" (Rz 8, 32). A swe własne życie tak ujmował: „Żyję wiarą w Syna Bożego, który umiłował mnie i samego siebie za mnie wydał" (Gal 2, 20). Na centralne miejsce wcielonego Syna Bożego w historii zbawienia ludzkości wskazują słowa Janowej ewangelii: „Tak Bóg umiłował świat, że Syna swego Jednorodzonego dał, aby każdy, kto w niego wierzy, nie zginął, ale miał życie wieczne" (J 3, 16).

Znowu egzystencjalny, hermeneutyczny sens wcielenia wynika $z$ jego przedmiotowych, metafizycznych treści, a w szczególności z uznania prawdziwości tezy, że Jezus jest prawdziwym Bogiem. Wszak tylko w tym założeniu sam Jezus za swego życia mógł zgłaszać żądania: „Wierzycie w Boga, i we mnie wierzcie" ( $J$ 14, 1); tylko pod tym warunkiem mógł zając w życiu Kościoła to miejsce, które rzeczywiście zajmuje.

Znowu metafizycznych treści dogmatu wiary w wcielenie nie można 
zastąpić sensem czysto egzystencjalnym, hermeneutycznym; tego rodzaju usiłowania prowadzą bowiem do odrzucenia preegzystencji Słowa oraz bóstwa Jezusa Chrystusa. Jeśli mianowicie przyjmiemy zasadę antropocentrycznej hermeneutyki, że byt każdego bytującego polega w swej najdalszej głębi na bytowaniu w odniesieniu do człowieka, to i preegzystencja i odwieczne istnienie Słowa są przez nią wprost wykluczone jak to już wyżej przy omawianiu dogmatu stworzenia, zauważono. Jeśli natomiast opowiemy się za zasadą hermeneutyki umiarkowanej, że rozumienie wiary jest rozumieniem siebie samego, to również w tym horyzoncie hermeneutycznym nie będzie miejsca na preegzystencję Słowa i bóstwo Jezusa Chrystusa; znajdzie się w nim to, ze względu na co Chrystus jest do nas podobny.

\section{WNIOSKI}

Powyższe analizy pozwalają na postawienie szeregu tez programowych, które zostaną przedstawione w trzech twierdzeniach.

Twierdzenie pierwsze: Nowa katolicka interpre-tacja naukowa dogmató musi mieć znaczenie przedmiotowe, a niekiedy metafizyczne. Można je wyrazić również w zdaniu przeczącym: Nowa katolicka interpretacja naukowa dogmatów nie może być całkowicie niemetafizyczna. Forma przecząca jest wyraźniejszą odpowiedzią na programowe sformułowania Geffrégo i innych teologów nowej linii.

Zachowanie tożsamości znaczeniowej między tłumaczeniem a tym, co jest tłumaczone, należy przecież do zasadniczego pojęcia i zadania jakiegokolwiek tłumaczenia, interpretacji. Jeśli tego zadania nie wypełnia, właściwie nie jest tłumaczeniem; nie jest interpretacją. Z drugiej strony jest faktem, że dogmaty są wypowiedziami o rzeczywistości przedmiotowej, czyli mają zawsze przedmiotowe i ontologiczne znaczenie. Niekiedy, jak nam okazała analiza podstawowych dogmatów stworzenia, opatrzności i wcielenia - ta przedmiotowa i ontologiczna rzeczywistość jest ponadto rzeczywistością metafizyczną w zawężonym, Heideggerowskim znaczeniu, które jest punktem wyjścia i odniesienia całej dyskusji. Wobec takiego stanu rzeczy jest bezwzględnie niemożliwe zbudowanie nowej interpretacji dogmatów całkowicie niemetafizycznej bez odrzucenia metafizycznych treści, stanowiących przedmiot podsta-wowych dogmatów katolicyzmu. Niemetafizyczna interpretacja zmienialaby istotnie przedmiotowy sens dogınatów katolicyzmu i dlatego nie byłaby interpretacją katolicką ani w ogóle interpretacją w znaczeniu właściwym. 
Twierdzenie drugie: Nowa katolicka interpretacja naukowa dogmatów z natury poznania teologicznego winna być również hermeneutyczna w tym znaczeniu, że rozumienie przedmiotowych treści dogmatów jest podstawą do rozumienia sytuacji człowieka.

Teologia jest rozprawą o Bogu i o wszystkim, co wiąże się z Bogiem. Ale sprawa Boga jest w pierwszym rzędzie zagadnieniem egzystencjalnym. Gdy pytamy o Boga, chodzi nam przede wszystkim o sens życia ludzkiego, które bez Boga jako celu ostatecznego przedstawia się nam jako pozbawione zasadniczego sensu. Rzeczywistą doniosłość dla sensowności egzystencji ludzkiej ma następnie i w jakimś stopniu także wszystko, co się wiąże z Bogiem; zatem wszystko, o czym przedmiotowo orzekają dogmaty i o czym rozprawia teologia. Ponieważ zaś zadaniem hermeneutyki jest odsłonięcie sensu egzystencji ludzkiej, przedmiotem hermeneutycznej analizy może się stać wszystko, o czym wyrokują dog.maty i rozprawia teologia.

Co więcej, z natury poznania teologicznego wynika, że teologia winna się zająć metodycznym poszukiwaniem egzystencjalnego sensu treści dogmatów. Teologia jest bowiem zbiorem metodycznie zdobytych odpowiedzi na pytania stawiane przez rozum pod adresem wiary. A rozumny człowiek nie może nie pytać o egzystencjalną doniosłość dogmatycznych treści, jako że one dopiero nadają głęboki sens życiu. Skoro więc rzeczywiście istnieje zagadnienie egzystencjalnego sensu dogmatów, teologia ze swej istoty winna je metodycznie stawiać i rozwiązywać.

Wobec tego teologia $\mathrm{z}$ istoty swej winna być równocześnie hermeneutyczna oraz ontologiczno-metañizyczna. I zawsze ten dwojaki charakter posiadała. Widać to już w teologii biblijnej. Gdy autorowie ksiąg Nowego Testamentu wnioskowali ze słów Chrystusa, że jest prawdziwym Bogiem, uprawiali teologię metafizyczną; kiedy pisali ,tak Bóg umiłował świat, że Syna swego jednorodzonego dał’" (J 3, 16) uprawiali hermeneutykę. W różnych okresach historii teologii akcenty bywały rozmaicie rozłożone. Dzisiaj jesteśmy świadkami przesady w ocenie roli teologii hermeneutycznej, bo niektórzy chcą usunąc teologię ontologiczno-metafizyczną i zastąpić ją przez teologię hermeneutyczną. W dobie wielkiej scholastyki natomiast teologia miała wyraźnie i metodycznie charakter ontologiczno-metafizyczny, a egzystencjalny sens dogmatów, nie był wprawdzie wykluczony, ale był traktowany bardzo marginesowo jako tzw. convenientia.

$\mathrm{Z}$ dwojakiego, tzn. ontologiczno-metafizycznego oraz hermeneutycznego, charakteru poznania teologicznego wypływa doniosły postulat praktyczny: Wykład teologii dogmatycznejnie jest 
pełny, jeśli nie przedstawia zarówno jego treści przedmiotowej, ontologiczno-metafizycznej, jak i jego egzystencjalnego sensu.

Aby np. dogmatyczny wykład o świętości Boga był pełny, nie wystarczy wyjaśnić, co znaczy, że Bóg jest samoistną świętością. Należy jeszcze wskazać, jakie następstwa pociąga za sobą świętość Boga w życiu człowieka. Trzeba więc dodać, że substancjalna świętość Boga z metafizyczną koniecznością domaga się posiadania świętości jako warunkı zjednoczenia z Bogiem. Z niej wypływa konieczność całkowitego oczyszczenia się z wszystkich grzechów tak, że ktokolwiek nie oczyści się z nich całkowicie za życia przez pokutę musi frzejść po śmierci przez bolesne oczyszczenie w czyśćcu. Tą drogą wskazaliśmy na związek między świętością Boga a ostatecznym celem naszego życia; czyli słusznie mówił I sobór watykański, że związek z celem ostatecznym może być źródłem niejakiego rozumienia tajemnic wiary (DS 3016).

Twierdzenie drugie określa również wzajemny stosunek między przedmiotowym znaczeniem dogmatów a ich sensem egzystencjalnym, hermeneutycznym: w katolicyzmie sens egzystencjalny dogmatów ani nie zastępuje ich przedmiotowej treści ontologiczno-metafizycznej, ani jej nie wyprzedza, lecz ją zawsze zakłada i jest od niej zależny. $\mathrm{Na}$ taki właśnie stosunek wskazuje analiza podstawowych dogmatów katolicyzmu, przeprowadzona w poprzednim ustępie oraz historia dog.matów. W świetle tegoż twierdzenia rozumienie wiary jest źródłem rozumienia siebie, ale się z nim całkowicie nie utożsamia; odpada zatem zasada egzystencjalistycznej teologii hermeneutycznej, która twierdzi, że rozumienie wiary jest rozumieniem siebie.

Twierdzenie trzecie: Bóg nie jest właściwym. przedmiotem dogmatycznych treści. Wyraża ono myśl, że zarzut, jaki Heidegger wytacza przeciw tradycyjnej metafizyce, że z Boga czyni przedmiot; że go obiektywizuje, — nie może być postawiony dogmatycznej nauce Kościoła zarówno o poznawalności Boga jak o Bogu samym. Wydawać się może, iż twierdzenie obecne stoi w oczywistej sprzeczności z faktami, bo przecież Bóg bywa podimiotem orzeczeń dogmatycznych; np. jest nim rzeczywiście w przytoczonym wyżej orzeczeniu dogmatycznym I soboru watykańskiego o opatrzności Bożej. Trudność znika, jeśli przeanalizujemy epistemologiczny charakter tych orzeczeń.

Naprzód w świetle dogmatycznej nauki o rozumowej poznawalności Boga. Ani Pismo św. ani dogmat wiary nie zna innej drogi do rozumowego poznania Boga jak tylko poprzez byty stworzone, per ea quae facta sunt (DS 3004). A przedmiotem właściwym, przypominamy, jest 
tylko to, co zostaje przez akt poznania ujęte wprost i bezpośrednio; wszystko natomiast, co bywa ujęte pośrednio, tj. za pośrednictwem drugiego przedmiotu, nazywa się wprawdzie przedmiotem $-\mathrm{z}$ braku lepszej nazwy - ale w innym, niewłaściwym znaczeniu; czyli właściwie i prawdziwie już nie jest przedmiotem. Skoro więc dogmat zna tylko jedną drogę do rozumowego poznania Boga, mianowicie poprzez byty stworzone, czyli poprzez świat, to zdobyta tą drogą wiedza o Bogu jest właściwie wiedzą o świecie; w niej tylko dlatego mówinıy o Bogu, ̀̇e bez Boga nie możemy rozumieć świata, i tylko tyle o nim mówimy, ile jest konieczne do zrozumienia świata. Chociaż więc Bóg jest podmiotem twierdzeń składających się na rozumową wiedzę o nim, to jednak nie On, ale świat jet właściwym przedmiotem tej wiedzy. Dogmatyczna treść nauki o rozumowej poznawalności Boga nie pozostawia miejsca na filozofię Boga, na metafizykę Boga. Chociaż istnieje filozofia przyrody, to w świetle dogmatycznej nauki Kościoła nie ma filozofii Boga, nie ma metafizyki Boga.

Sw. Paweł - 1 Kor 13, 12 - scharakteryzował całe nasze poznanie Boga, dopóki żyjemy na ziemi, jako poznanie przez zwierciadło, per speculum. To obrazowe określenie ujmuje niezwykle jasno i trafnie jego epistemologiczny charakter. Sytuacja człowieka poznającego Boga jest taka sama jak sytuacja kogoś, kto ogląda w lustrze odbijający się w nim krajobraz. Jeśli powie, że widzi krajobraz, wyrazi się niewłaściwie i nieściśle; właściwie widzi bowiem w lustrze tylko odbicie, tylko obraz krajobrazu. Mówiąc „widzę krajobraz” dokona językowego skrótu i uproszczenia. Tak samo rzecz się ma $z$ naszą wiedzą o Bogu i z naszymi wypowiedziami o nim. Nie dosięgamy w niej samej rzeczywistości substancji Bożej, ale tylko jej nikłe podobizny w świecie stworzonym i o nich w naszych wypowiedziach orzekamy, chociaż drogą językowego skrótu mówimy „B̈óg” dlatego, że nie chodzi nam o podobieństwa względnie niepodobieństwa, dostrzeżone w świecie, ale o tego, na którego one wskazują.

1 Kor 13, 12 całe poznanie Boga, dostępne za życia, uznaje za poznanie przez zwierciadło, podobieństwo; również i poznanie tajemnic Boga, które się staje naszym udziałem wyłącznie drogą nadprzyrodzonego objawienia Starego i Nowego Testamentu. Albowiem przemawiając do nas Bóg posługuje się naszym ludzkim językiem i ludzkimi pojęciami; a ludzkie słowa i pojęcia służą właściwie do oznaczenia rzeczywistości świata; dlatego nie są zdolne powiedzieć, kim Bóg jest, ale jedynie wskazać pod jakim względem jest podobny a pod jakim jest niepodobny do bytów świata przez te pojęcia i słowa oznaczonych.

Zatem Bóg, w świetle tej nauki, właściwie i ściśle mówiąc nie jest przedmiotem żadnego pojęcia i żadnej wypowiedzi. Ich przedmiotem. 
czyli tym co one wprost i bezpośrednio czyli właściwie przedstawiają jest jedynie stworzone podobieństwo względnie niepodobieństwo stworzenia do Boga, a nie rzeczywistość niestworzona jestestwa Bożego. W naszych wnioskowaniach i wypowiedziach o Bogu nie manipulujemy Bogiem i nie dominujemy nad nim, ale jedynie nad stworzonymi podobieństwami Boga i nimi tylko manipulujemy.

Po wtóre, tym bardziej katolicka nauka o Bogu wyklucza manipulowanie Bogiem jako przedmiotem i dominowanie naszego rozumu nad nim, że z każdą wypowiedzią o Bogu wiąże nierozerwalnie tajemnicę. Albowiem powiada IV sobór lateraneński, że ,nie można wskazać takiego podobieństwa między stwórcą a stworzeniem, żeby nie było większego między nimi niepodobieństwa" (DS 806). Jeśli więc np. ze względu na podobieństwo do stworzeń musimy twierdzić, że Bóg jest mądry to zgodnie z wyjaśnieniem IV soboru lateraneńskiego - musimy uzupełnić nasze twierdzenie zastrzeżeniem: Mądrość Boga jest bardziej niepodobna niż podobna do mądrości stworzeń. Wobec tego powstaje pytanie: „Jaka ona właściwie jest i czym właściwie jest?" To jest tajemnicą, której nie można wyświetlić tak długo, jak długo mówimy o Bogu przez podobieństwa, czyli przy pomocy pojęć i nazw, których właściwym przedmiotem są byty stworzonego świata. Uznanie tajemnicy wymaga ,posłuszeństwa”, poddania się rozumu; wyklucza jego dominację.

\section{JAKA METAFIZYKA JEST IMPLIKOWANA PRZEZ TRESC DOGMATÓW?}

W tym, ostatnim ustępie naszego rozważania jest mowa o metafizyce w szerszym, tradycyjnym znaczeniu, a nie w Heideggerowskim i zawężonym, jakie w poprzednich ustępach zostało nam narzucone przez dyskusję nad niemetafizycznym charakterem nowej teologii. Za metafizykę czyli ontologię będziemy zatem uważać rozprawę o bycie tak materialnym jak niematerialnym, tak skończonym jak nieskończonym. W tym znaczeniu zagadnienie duszy i wewnętrznej konstytucji natury ludzkiej będzie należało do metafizyki czyli ontologii.

Powstało w ciągu wieków wiele systemów filozofii metafizycznej, spośród których najbardziej żywotne i wpływowe okazały się dwa: platonizm oraz arystotelizm, uprawiany do dnia dzisiejszego głównie pod postacią tomizmu. Stawiając pytanie, jaka metafizyka jest implikowana przez treść dogmatów, nie zamierzamy bynajmniej wskazywać na jakiś jeden, określony system filozoficzny - np. na tomizm — jako całość, albowiem w każdym systemie - nawet w tomizmie - znajdują się tezy, które nie są implikowane przez treść dogmatów. Chodzić nam będzie o konkretne twierdzenia metafizyczne, niezależnie od tego, z jakiego systemu filozofii pochodzą. Nie będziemy się jednak silić na sporzą- 
dzanie wykazu tych twierdzeń. Zadaniem stojącym przed nami jest znalezienie wspólnego mianownika, cechy wspólnej dla wszystkich twierdzeń metafizycznych, implikowanych przez treść dogmatów. Wszak każda interpretacja, jeśli prawdziwie jest tłumaczeniem, musi zachowywać treściową tożsamość z tym, co interpretuje. Wobec tego tylko te tezy metafizyczne nadają się do interpretacji dogmatów, które są przez ich treść implikowane.

Pytamy zatem, jaki musi być ten zasób twierdzeń metafizycznych, który jest nieodzownie konieczny do katolickiej interpretacji teologicznej dogmatów. Filozoficzna teoria hermeneutyki nazywa taki zasób p r zedrozumieniem, Vorverstehen, Vorverständnis. Mamy zatem udzielić odpowiedzi na pytanie, $\mathrm{z}$ jakim metafizycznym przedrozumieniem musi teolog przystępować do interpretacji dogmatów, by jego interpretacja pozostawała w zakresie tej samej treści co dogmaty.

Dogmaty są tylko wyjaśnieniem treści objawienia; więc albo bezpośrednio albo pośrednio wyjaśnieniem treści Ewangelii. Są także przeznaczone dla tych samych odbiorców co i Ewangelia, którą wyjaśniają. A Chrystus przeznaczył Ewangelię dla wszystkich ludzi bez żadnego wyjątku. Nie tylko bowiem kazał ją głosić wszystkim narodom (Mt 28, 19), ale przyjęcie jej aktem wiary podniósł do rzędu warunku nieodzownie koniecznego do zbawienia ( $\mathrm{Mk} 16,16)$. Tak samo Kościół do wszystkich ludzi kieruje swe nieomylne czyli dogmatyczne wyjaśnianie Objawienia. Wynika stąd odpowiedź na pytanie postawione przez nas.

Przedrozumienie nieodzownie konieczne do teologicznej interpretacji dogmatów obejmuje tylko intuicje, pojęcia i twierdzenia metafizyczne, stanowiące wspólny dorobek całej ludzkości, patrimonium commune et perenne. Natomiast te intuicje, pojęcia i twierdzenia, które nie są wspólnym dorobkiem ludzkości, nie są konieczne ani do przednaukowego rozumienia ani do naukowej interpretacji objawienia i dogmatów. Jeśli bowiem Chrystus - i Kościół - rzeczywiście przeznacza Ewangelię dla wszystkich ludzi, wszystkich stanów, wszystkich kultur, to nie może uzależniać jej przyjęcia rozumnym aktem wiary od warunku, którym nie rozporżądzają wszyscy ludzie wszystkich czasów. W tym właśnie znaczeniu należy rozumieć ,wi e kuisty do robek filoz oficzny, patrimonium philosophicum perenne”, który w myśl soborowego dekretu Optatam totiu $(15,3)$, o wychowaniu do kapłaństwa, winien być przedmiotem nauczania w seminariach duchownych.

W minionej niedawno dobie panowania klasycznego tomizmu jego zwolennicy za wieczystą filozofię uważali właśnie ten tomizm, wyrażony w 24 tezach, ogłoszonych przez Kongregację Studiów 24 VII 1914. Wiele 
z nich na pewno nie jest przedzrozumieniem koniecznym do interpretacji dogmatów. Jeśli więc filozofowie chrześcijańscy chcą się przysłużyć rozumieniu Ewangelii oraz teologicznej interpretacji dogmatów, winni swe wysiłki ześrodkować na dokładniejszym określeniu i na pogłębieniu tego, co prawdziwie jest wspólnym metafizycznym dorobkiem. 